\title{
LOS PUEBLOS ORIGINARIOS DEL NORTE DE CHILE Y EL ESTADO*
}

\author{
THE NATIVE PEOPLES OF NORTHERN CHILE AND THE STATE
}

\author{
Hans Gundermann Kröll**
}

\begin{abstract}
El artículo propone una síntesis de la relación histórica moderna de los pueblos originarios del norte del país con el Estado chileno, destacando su particularidad por relación con otros grupos indígenas. Esa especificidad proviene de la preeminencia, desde finales del siglo XIX, de las definiciones nacionales de pertenencia de los grupos sociales existentes en esta extensa región anexada por Chile y, en consecuencia, de políticas estatales y prácticas de re"lación según esos términos. Esto es, según la condición de nacionales y extranjeros. Los procesos de asimilación de los extranjeros (en realidad, nativos de la zona), llamados de "chilenización", se realizaron con arreglo a ese principio de adscripción. La adjetivación de "indio" se aplicó a segmentos de personas peruanas y bolivianas de la región andina, expresando con ello no diferencias étnicas sino la carencia de civilización y progreso de los integrantes de esas nacionalidades. Se presenta una periodificación histórica que atiende a transformaciones en las relaciones entre Estado y pueblos originarios. Primero, la integración de poblaciones extranjeras en los márgenes geográficos regionales (1879-1961); luego, un periodo marcado por acciones de integración, desarrollo, un mayor interés geopolítico por las fronteras andinas e incipiente percepción de las diferencias culturales de su población (1961-1993); finalmente, uno de reconocimiento étnico a partir de la promulgación de la Ley No 19.253 en 1993, que identifica una etnia aymara, otra atacameña, una quechua y, más tarde, otra coya y diaguita.
\end{abstract}

Palabras claves: Pueblos indígenas, norte de Chile, políticas públicas, reconocimiento.

The article proposes a synthesis of the modern historical relationship between indigenous groups in the north of the country and the Chilean State, emphasizing its particularities in opposition to other originary groups. This specificity stems from the preeminence of the national definitions of belonging inside the social groups that exist in this vast region annexed by Chile, since the end of the 19th century. Consequently, this also stems from the state policies and relationship practices according to the terms mentioned above, this means: the condition of national or foreign person. The assimilation processes of foreigners (as a matter of fact, natives of the area), is called "chilenización" and were carried out according to the principle of ascription. The adjective of "indio" was applied to segments of Peruvian and Bolivian people of the Andean region, expressing with it not ethnic differences but the lack of civilization and progress of the members of those nationalities. Here we present an historical account that deals with transformations in the relations between the State and indigenous peoples. First, the integration of foreign populations in the regional geographical margins (1879-1961).Second, a period marked by integration actions, development and a geopolitical interest in the Andean border joined to an incipient perception of the cultural differences of its population (1961-1993). And finally, one of ethnic recognition in the enactment of Law No. 19.253 in 1993, which identifies Aymara, atacameño, Quechua and, later, Coya and Diaguita ethnic groups.

Key words: Indigenous groups, North of Chile, public politics, recognition.

\section{Introducción}

Este artículo aborda la relación entre el Estado de Chile y los pueblos originarios del norte del país, en el presente el pueblo aymara, atacameño o likanantay, quechua, colla y diaguita ${ }^{1}$. Entendemos al Estado como un conjunto heterogéneo de instituciones, organizado formalmente, con niveles de jerarquía y divisiones, en que grupos políticos de la sociedad disputan su control con arreglo a reglas de acceso, que impulsan agendas de cambio social y desarrollo, así como la reproducción y cambio de intereses de clase. Se encuentra cruzado por incoherencias, ambigüedades y dinámicas de producción y reproducción no lineales. Los agentes del Estado corresponden a autoridades, burócratas, representantes, operadores políticos y empleados, distribuidos en una compleja red de posiciones y relaciones de poder político y burocrático. Desestimamos, entonces, la visión del Estado como un centro unitario, vertical y omnipotente, para abrirnos a una comprensión más matizada, capaz de reconocer especificidades históricas locales y zonales. Los pueblos originarios, a su vez, comprenden realidades regionales con

* Resultado Proyecto Fondecyt No 114077 y del Proyecto Fondecyt No 1150573.

** Universidad Católica del Norte (UCN), Instituto de Investigaciones Arqueológicas y Museo (IAAM). San Pedro de Atacama, Chile. Correo electrónico: hgunder@ucn.cl 
historias singulares, cuyos integrantes se conciben compartiendo una aboriginalidad específica, sostenida por una memoria común, real e imputada; por redes, grupos e instituciones locales y regionales; así como en una visión de futuro, cuyo cumplimiento se presupone sustentado en fuerzas internas, pero también externas en que al Estado cabría un papel protagónico de reconocimiento, justicia, reparación, otorgamiento de derechos y desarrollo. Esta relación, como bien lo muestran los casos de las etnias del norte del país, no es posible considerarla predeterminada o unidireccional, como tampoco una de antagonismo o resistencia persistente, sino que con signos políticos cambiantes. Los propios sujetos indígenas, particularmente los andinos que aquí tratamos, difícilmente pueden encasillarse en una unidad histórica continua carente de cambios estructurales, ambigüedades y contradicciones ${ }^{2}$.

La relación entre Estado chileno y pueblos indígenas del norte del país es moderna, menos por lo comparativamente reciente de sus inicios, que por los atributos de ese Estado, las realidades indígenas regionales y las formas de relación desplegadas. Para su descripción consideramos de interés proponer una periodificación sustentada en los cambios de la relción estudiada, partiendo por las décadas de 1880 hasta el año 1961, en que tiene lugar la anexión de los territorios del más tarde llamado Norte Grande y la integración de sus pobladores ${ }^{3}$. Entre ellos los indígenas, en los márgenes geográficos regionales y persistentemente representados como extranjeros. A continuación, un periodo de poco más de tres décadas (1961-1990), caracterizado por una profusa acción estatal para el desarrollo local y la integración de las zonas andinas a sus regiones; en la última etapa siguiendo lineamientos geopolíticos. Es el periodo en que la acción pública hacia los indígenas empieza a tratar los "indios" o "indígenas" como sujetos colectivos y se asiste a las primeras acciones hacia ellos con arreglo a esa definición. El tercer y último momento, arranca con el retorno a la democracia y lo caracteriza el impulso otorgado desde el Estado al reconocimiento étnico, que en su despliegue termina entrando en tensión y conflicto por las demandas indígenas de territorio y autonomía. Se han propuesto otras periodificaciones en los estudios de historia social y antropología histórica que abordan las poblaciones indígenas del norte del país (por ejemplo, González, S. 2002a para el caso aymara; Comisión de Verdad Histórica y Nuevo Trato, 2008: 79-225 para los pueblos originarios del norte del país; el mismo autor, Gundermann, 2001; también Díaz et. al., 2013). Procedimos en este trabajo a organizar la información utilizada y análisis de ella enfatizando los cambios en la relación pueblos originarios-Estado, especialmente los que se generan por innovaciones legislativas y de la acción pública hacia los sujetos indígenas.

\section{Disputa internacional, “chilenización” e integración de poblaciones extranjeras y en los márgenes geográficos regionales (1880-1961)}

La anexión de los territorios de Antofagasta, Tarapacá y Arica, antes provincias de Bolivia y Perú, respectivamente, como consecuencia de la ocupación militar, la guerra y su resolución mediante tratados, incorporó varias poblaciones de indígenas a la soberanía de Chile. De distintos orígenes y localizaciones, es admisible insistir: grupos regionales en el espacio andino de Arica, Tarapacá e interior de Antofagasta. Pero también, más tarde, inmigrantes de habla quechua de Cochabamba en calidad de obreros a la industria del salitre. Asimismo, remanentes de pescadores indígenas de la costa, poco definibles lingüística y culturalmente salvo por su oficio de pescadores pobres. Corresponde sumar a ellos ocupantes mestizos e indígenas en las cordilleras de Copiapó y Chañaral, en los límites meridionales de las regiones anexadas, en su mayoría provenientes de las provincias del noroeste argentino, que darán origen contemporáneamente a la etnia Colla. O bien, pobladores de localidades que en el pasado fueron "pueblos de indios" coloniales en los valles interiores del sur de la región de Atacama y norte de la de Coquimbo, de los que surgirán hace unos años las comunidades "diaguitas".

La legislación y políticas del Estado de Chile aplicadas en las regiones incorporadas al territorio nacional por la Guerra del Pacífico no se dirigieron a los indígenas en tanto grupos regionales y a pesar que pudieran ser demográficamente significativos. A fines del siglo XIX y primeras décadas del siglo XX la legislación y política indígena estaba referida a la situación mapuche del centro sur del país. No hubo legislación que los considerara, aun por extensión, sino hasta bien avanzado el siglo pasado, con la Ley $\mathrm{N}^{\circ} 14.511$ de 1961 . Y prácticamente sin nombrarlos, dejándolos bajo el genérico "indígenas". No se trata que fuera desconocida la existencia de indígenas en las áreas interiores y 
fronterizas de estas regiones, pero no fueron materia de legislación o acción pública en tanto que "indios" o "indígenas" y todavía menos en tanto que etnias o pueblos originarios ${ }^{4}$. La atribución de indígena aparece como una adjetivación antes que como un substantivo que nombra una agrupación social extensa. Son adjetivaciones relativas a significaciones contenidas en las nociones de "civilización" y "progreso", con que se evaluaba social, económica, cultural y moralmente categorías sociales tan diversas en los países andinos como los sectores de pobreza, grupos en los márgenes geográficos, u otros nacionales y a los indígenas (Gundermann, 2001; Gundermann et al., 2003). Cuando se les nombra, ello no ocurre según conceptos que los definan como sujetos étnicos, sino que en términos estrictamente nacionales ("chilenos", "peruanos", "bolivianos", "argentinos" como a todos los habitantes de la región); económicos (“campesinos", "pequeños agricultores", "pobres del campo") y residenciales ("pobladores" de tal lugar, "rurales", "del interior", "paisanos"). La percepción interna como "indios" o "indígenas" de origen colonial, correspondía con la definición social externa y a veces fiscal empleada (caso boliviano respecto de los indígenas de la provincia de Atacama), o se encontraba en transición hacia adscripciones puramente nacionales (en especial, el caso de la población peruana de los valles de Arica y Tarapacá) (González, H., 2002; también Díaz, comp., 2006; Díaz, 2006; Díaz y Ruz, 2009). Ella coexistía con adscripciones locales cultural y socialmente significativas.

Se ha generalizado la idea, siguiendo a Van Kessel (1981), que los gobiernos chilenos aplicaron una consistente y generalizada acción de "chilenización" hacia aymaras, atacameños, y en general los habitantes peruanos y bolivianos de las regiones anexadas. Por "chilenización" se entiende el cambio de sentido de pertenencia nacional en favor de la nacionalidad chilena, la lealtad a sus autoridades de gobierno y transformaciones en la subjetividad y modos de vida, en la senda del progreso y la civilización que mejor encarnarían la sociedad y el Estado chilenos. Lo señalado es particularmente cierto para las provincias de Tacna y Arica, bajo dominio chileno entre 1880 y 1929 , cuya restitución al Perú o incorporación a Chile dependía de un plebiscito, por lo demás nunca realizado. Es lo que Sergio González ha llamado “chilenización compulsiva” (González, S., 1997;
González S., et al., 1994). Pero ello aplicaba solo para Tacna y Arica, no exactamente para Tarapacá, cedido a Chile en el Tratado de Ancón de 1883. De hecho, aquí los residentes peruanos pudieron mantener su condición nacional originaria si así lo eligieron (González, S., 2002), aun cuando sujetos a la administración y autoridades chilenas, a la educación en escuelas chilenas, expuestos al proselitismo religioso de sacerdotes chilenos y a presiones políticas y momentos de violencia muy concretas (consúltese también a Díaz et al, 2010, Díaz et al, 2013). Y tampoco aplicaba para Antofagasta, ajeno a la situación política especial de las provincias septentrionales incorporadas y con una población boliviana poco numerosa y menos activa políticamente. En cualquier caso, en este cuadro los indígenas no están presentes como un sujeto político o social relevante y notorio. Son procesos cuyas consecuencias los alcanzan y de los que en ciertos aspectos son partícipes, pero en tanto que ciudadanos peruanos, o bolivianos más al sur. Salvo por defecto, no se trata entonces de la "chilenización" del indígena, sino de los peruanos y, particularmente en una región, aquella cuya soberanía estaba pendiente de resolución y en disputa con Perú. Se trata de una disputa por la nacionalidad y las lealtades nacionales y no por la integración del "indio". Como se aprecia, no participamos de aquella visión o apelación que sin mayor precisión terminológica y resguardos metodológicos traslada categorías y conceptos contemporáneos a la interpretación de procesos sociales del pasado, sus actores sociales, lenguajes políticos, marcos institucionales y circunstancias locales. Ello se alza como un obstáculo teórico y metodológico para una comprensión debidamente contextualizada del pasado.

Los indígenas de Antofagasta, Tarapacá y Arica fueron tratados en materia de gobierno, administración y legalidad aplicable sin ninguna excepción o consideración particular. Se impuso un régimen administrativo estructurado en provincias o departamentos, subdelegaciones y distritos con cabeceras políticas en los puertos de la costa, reformando la anterior organización administrativa peruana y boliviana. Es del caso destacar, no obstante, los roles y funciones que en el ámbito ritual, social o de coordinación comunitaria cumplieron desde posiciones subalternas, a veces en paralelo, personeros como los caciques o mallku en comunidades como las de Isluga y Cariquima, o los oficiantes 
de la ritualidad asociada al riego en valles de la precordillera andina aymara y atacameña.

Respecto de cada una de las jurisdicciones administrativas se nombraban autoridades y funcionarios. Los distritos andinos normalmente contaron con personeros designados entre los vecinos considerados influyentes e ilustrados (Subdelegados, Inspectores de Distrito, Jueces de Distrito) (Díaz et al., 2004). La excepción correspondió a Tacna y Arica, principalmente entre 1910 y 1929, donde se hicieron esfuerzos por trasladar a ciudadanos chilenos con probada adhesión y lealtad nacional, debido a la particular situación política y diplomática que hasta 1929 vivió esa región. Si bien ello se logró, con intermitencias, en los valles costeros y en los principales poblados de la precordillera, para los sectores más distantes y aislados esa condición fue mucho más difícil de realizar. Un esfuerzo similar, extensible a Tarapacá, puede señalarse con el profesorado de las escuelas públicas, entre cuyos integrantes se vio agentes fundamentales para la inculcación de símbolos y significados nacionales chilenos. Contribuyó lo suyo, asimismo, la conscripción militar de los jóvenes varones. El reemplazo de curas católicos peruanos por sacerdotes de la vicaría castrense chilena cumplió una función ideológica equivalente (Tudela, 1991; 2002, González S., 2002; Díaz, 2006; Díaz y Ruz, 2009). Los agentes de la administración, los funcionarios judiciales, la policía y fuerzas armadas, los docentes de las escuelas e, incluso, el clero chileno desplegado en las regiones anexadas, por lo común cumplieron con celo las funciones que les eran propias y se impusieron la tarea de difundir e imponer las virtudes del EstadoNación chileno. Esa visión virtuosa se sustentó en la imagen de la condición organizada, ordenada y eficaz del Estado, la unidad y homogeneidad de su población, el mayor progreso y civilización de su sociedad, incluso la superioridad moral de sus autoridades, todo ello les otorgaba un sentido de supremacía manifiesto. Los indígenas andinos se encontrarían en el extremo más alejado de esos valores de progreso y civilización.

Respecto de la propiedad de la tierra se aplicó la ley chilena común. Esto es, que los particulares que poseyeran tierras u otros bienes raíces debían inscribirlos en los registros de los Conservadores de Bienes Raíces de su jurisdicción (Antofagasta, Iquique, Pisagua y Tacna, después Arica). Y todo aquello que no fuera demostradamente particular quedaba cubierto por inscripciones de mayor cabida en favor del fisco chileno. Las comunidades de tierras atacameñas todavía vigentes bajo la administración boliviana, y las aymaras más al norte en proceso de disolución respecto de sus derechos sobre la tierra (Gundermann y González, H., 1997), fueron completamente desconocidas como sujetos jurídicos, políticos e incluso sociológicos. Desde la temprana instalación de los Conservadores de Bienes Raíces se activaron las inscripciones de chacras y pastizales en los valles y cordillera andina. En cosa de unas pocas décadas prácticamente todas las tierras indígenas y no indígenas de uso agropecuario de Tarapacá y Arica estaban inscritas como propiedad particular. En la zona del río Loa y el Salar de Atacama el inicio de los registros de propiedad es algo más tardío y menos masivo, quedando las áreas de pastoreo no regularizadas en su gran mayoría. Las consecuencias de este proceso son varias. Primero, se refuerza el principio de la tierra como propiedad particular susceptible de enajenación. Segundo, se liquida cualquier reconocimiento jurídico y poder formal de las comunidades sobre el uso y disposición de la tierra; en los hechos, se mantuvieron algunas regulaciones aplicadas localmente (por ejemplo, respecto de la distribución del agua; o la organización social informal del manejo ganadero). Y tercero, contra lo esperable, en las tierras de pastoreo altoandinas de Tarapacá y Arica surge una nueva forma de colectividad conocida como "comunidad sucesorial" sostenida en las antiguas estancias pastoriles de las comunidades y pueblos indios coloniales ${ }^{6}$. Ella no se desarrolla de igual manera en la "puna" de Atacama chilena y argentina donde prevaleció un acceso familiar flexible a las estancias de pastoreo, basado en pertenencias a ayllus o pueblos históri$\cos$, sin que para cada estancia pastoril o grupos de ellas se formaran comunidades sucesoriales nuevas, ancladas por titulaciones modernas como en las regiones septentrionales indicadas.

Resuelta la anexión de Arica a Chile en 1929, confirmada la incorporación de Antofagasta y Tarapacá mediante tratados con Bolivia, Perú y Argentina y definidas en lo sustancial las fronteras andinas con esos países, la acción pública hacia los poblados y comunidades andinas entrega una imagen políticamente menos dramática; no obstante, se constatan cursos de acción y cambios dignos de mención. Ellos responden a la culminación de la minería salitrera en el desierto intermedio, que abrió una paralela crisis económica en las regiones interiores y en la articulación que las regiones 
andinas habían sostenido con la industria minera, obligando a diversos reacomodos. Hablamos de la minería del salitre y de la minería andina presente en el periodo. Esta última conoce de términos (como la extracción de bórax en Ascotán, plata y oro en Collahuasi o en Choquelimpie), pero también aperturas y ampliaciones (como la del cobre en Chuquicamata y, más adelante, un ciclo de extracción de azufre desde volcanes andinos en Arica y Antofagasta).

Con la crisis salitrera la economía agropecuaria de los campesinos andinos deja de tener un volumen de demanda y valorización de productos como la que conoció durante el ciclo expansivo de la minería regional (forrajes, ganado, chacarería) y las posibilidades de trabajo asalariado en las industrias extractivas disminuyen. Ello condujo, por una parte, a la retracción hacia economías menos mercantilizadas y, por otra, a iniciar emigraciones, principalmente hacia los centros mineros subsistentes y los puertos nortinos (González, H. 1996a y 1996b; Gundermann, 2001). Planes de desarrollo promovidos por el Estado tocaron las zonas andinas, en respuesta a la situación económica que vivía el norte del país. Por ejemplo, los proyectos de activación agrícola en los principales valles, oasis y áreas del pie de desierto con potencial agropecuario: el tranque de Caritaya para el valle de Camarones; el tranque de Pachica nunca construido en la Quebrada de Tarapacá; o la conducción de aguas desde el río Lauca al valle de Azapa y, como primer objetivo, generar electricidad en Chapiquiña; o las acciones de la Corporación de Fomento CORFO para la activación de la economía agrícola en la Pampa del Tamarugal o en el oasis de San Pedro de Atacama. Estos esfuerzos llevaron a la apertura y mejoramiento de caminos, generaron empleos temporales y conllevaron activación económica en las áreas en que se insertaron. Pero como no prosperaron o lo hicieron a muy largo plazo (agricultura del valle de Azapa, por ejemplo), denotaron un aumento de la acción del Estado en pos del desarrollo de zonas andinas que no condujo a ningún dinamismo perdurable de su economía.

Otras oportunidades se abrieron, sin embargo, a partir de la acción desarrollista del Estado. Destaquemos algunas que consideramos de importancia. Hacia fines del periodo que describimos el dinamismos regional generado por el Puerto Libre de Arica y la Junta de Adelanto de Arica (desde mediados de la década de 1950) activaron el comercio fronterizo y de productos altoandinos (como la lana de camélidos) en el que arrieros e intermediarios indígenas fueron activos participantes. Lo que se suma a otras actividades de aprovisionamiento de centros mineros o urbanos (como la llareta en Antofagasta o la queñua para Arica) aprovechando las rutas ferroviarias de Arica-La Paz y AntofagastaBolivia). El movimiento de mercancías en zonas de frontera fue por momentos intenso, hacia y desde Bolivia y Perú, de manera legal y muchas veces ilegal. Lo que acarreó, como en otros momentos previos en que se establecen circuitos de comercio ${ }^{7}$, una mayor preocupación por el control policial de flujos de mercancías en esas áreas limítrofes.

Por otra parte, el cierre de la mayoría de las escuelas públicas en las oficinas y pueblos de la zona salitrera de Tarapacá permitió atender una sentida demanda por la instalación de servicios escolares en la precordillera andina, primero, y en los valles altos y altiplano, después. La instalación de escuelas es incluso anterior en la precordillera de Arica. Hacia fines de la década de 1950 prácticamente todo el espacio andino de Tarapacá quedó cubierto por una red de escuelas primarias que dieron un impulso decisivo a la integración cultural, ideológica y lingüística de las poblaciones indígenas andinas a Chile. De una manera menos notoria, similares impulsos se vivieron en las tierras altas de Arica y los pueblos y comunidades de la precordillera de Antofagasta (Gundermann et al., 2011). Se asiste así a la expansión de las comunicaciones terrestres y a la instalación de servicios escolares y requerimientos de mayor seguridad y control en las fronteras. Es esencial insistir que ellas tuvieron una muy activa contraparte en las propias comunidades y pueblos andinos mediante la persistente manifestación de demandas de desarrollo local. Asimismo, cobra notoriedad por esas décadas la figura organizativa conocida como "Comités de Adelanto" o "Juntas para el Progreso", basadas en asambleas y organizaciones locales e impulsadas por dirigentes, líderes y vecinos influyentes, particularmente motivados por sacar a sus comunidades del estado de postración, atraso, aislamiento y falta de progreso con que definían su situación. Visión que lleva a constatar la fuerza con que por esos momentos se habían incorporado objetivos de cambio social modernizador mediante la integración a la región y el país (espacial, económica, social, lingüística); cursos de acción analizables políticamente como demandas de ampliación de ciudadanía. 


\section{Integración, desarrollismo y geopolítica de los indígenas del norte del país (1961-1990)}

A partir de 1961 la legislación nacional reconoce y señala como materia de acción estatal a una pluralidad de comunidades u organizaciones indígenas, a pesar de su persistente foco mapuche ${ }^{8}$. El decreto que fija dependencias, atribuciones y plantas de la Dirección de Asuntos Indígenas (DASIN) indica que quedará radicado en este organismo "Investigar y estudiar las condiciones sociales, jurídicas y económicas de todas las comunidades o agrupaciones indígenas que hubiere dentro del territorio nacional y proponer las medidas conducentes al mejoramiento de dichas condiciones" (Art. 1, DFL 1/950 de 7-9-1961). Al amparo de este mandato se generaron algunas ayudas para localidades, todavía no especificadas étnicamente, del norte chileno. Desde mucho antes las comunidades rurales de toda la región andina norte estaban siendo alcanzadas directa e indirectamente por la acción pública, pero ello todavía no ocurría desde o a partir de un reconocimiento más amplio como "indígenas", y nada en lo absoluto como "aymaras" o "atacameños".

Tampoco el texto de la Ley Indígena N ${ }^{\circ} 17.729$ de septiembre de 1972 recoge una identificación y cursos de acción explícitos en materia de indígenas del norte de Chile. La indicada ley señala que serán indígenas aquellos "Que, habitando en cualquier lugar del territorio nacional, forme parte de un grupo que se exprese habitualmente en un idioma aborigen y se distinga de la generalidad de los habitantes de la República por conservar sistemas de vida, normas de convivencia, costumbres, formas de trabajo o religión, provenientes de los grupos étnicos autóctonos del país" (Ley No 17.729, art. 1, acápite $3,1972)$. No se hace una enumeración explícita de cuáles son ellos, como sí ocurre décadas más tarde con su sucesora la Ley $\mathrm{N}^{\circ} 19.253$ de 1993. Esa misma falta de precisión aparece en el Mensaje Presidencial de Salvador Allende de 1972, donde se consignan agrupaciones territoriales en las que se encuentran indígenas del "Norte Grande" y "algunos sectores de las provincias de Coquimbo y Atacama" (Gobierno de Chile, 1972) ${ }^{10}$. En cambio, el director de DASIN en la ponencia que presentó en el VII Congreso Indigenista Interamericano de Brasilia, en agosto de 1972, se preocupa de pormenorizar mucho más: "Región Norte: Quechuas, Aymaras, Atacameños y Diaguitas. Están ubicados desde el extremo norte del país, abarcando las provincias de
Tarapacá, Antofagasta, Atacama y Coquimbo. Suma aproximadamente 60.000 personas en la zona rural" (Colompil, 1972:3). Enumeración que constituye la base de la distribución étnica que recoge la política indígena originada con el retorno a la democracia en el Chile de la posdictadura.

El periodo analizado se puede caracterizar según dos momentos, ambos activamente desarrollistas y de integración de los espacios andinos a sus regiones, con enfoques distintos, pero igualmente de presencia estatal y control de fronteras. En el segundo, bajo el gobierno autoritario, se presenta una definida impronta geopolítica. Destaca en la documentación de la época y los testimonios una sostenida acción en materia de construcción de caminos para vehículos motorizados, que buscaban conectar poblados y comunidades con enlaces ferroviarios, centros urbanos del desierto y establecimientos mineros (ferrocarriles Arica-La Paz, o Antofagasta- Bolivia, la ciudad de Calama, el centro cuprífero de Chuquicamata, o con Copiapó más al sur) y las ciudades portuarias de la costa (Arica, Iquique, Antofagasta, Tocopilla). Esa infraestructura ferroviaria y de caminos existía previamente, pero faltaba la mayoría de las conexiones con los poblados de la precordillera y cordillera andina. A lo anterior debe agregarse la persistente demanda por infraestructura y servicios educacionales, que por esa época ya se había activado en favor de las localidades más distantes de la región andina. La demanda e instalación de otros servicios como dotaciones de policía en la frontera y los pueblos mayores, o los nombramientos de jueces e inspectores de distrito, la presencia de delegados municipales en algunos sitios importantes, o las campañas sanitarias completan un cuadro que podemos denominar integración convergente desde una perspectiva desarrollista.

En efecto, la década de 1960 e inicios de la siguiente es, con variantes, la de gobiernos con proyectos de desarrollo, participación popular e integración territorial, de manera notoria mediante la acción de la Corporación de Fomento (CORFO) o el Plan Andino de la Junta de Adelanto de Arica, políticas como la de la Promoción Popular (Gobierno de Frei, 1964-1970), o desarrollo local y ampliación de derechos sociales y políticos en las zonas interiores (Gobierno de Allende, 19701973). Tiene lugar una mayor inversión pública en áreas críticas para la integración y desarrollo de las zonas interiores (vialidad, infraestructura de riego y drenaje, construcción y mejoramiento de 
escuelas), así como el fomento de organizaciones de base de nuevo cuño: Juntas de Vecinos, Centros de Madres y clubes deportivos, alentadas por la participación popular. También se asiste a la creación de cooperativas que permitieran organizar mejor la producción agropecuaria y su comercialización. Todas ellas fueron iniciativas de la época. Es importante enfatizar que el impulso de integración regional y desarrollo local estaban para esa época muy presentes en las demandas de pueblos y comunidades ante las agencias públicas, con un notorio compromiso activo en su consecución. Y respecto de ello, sea o no que la acción estatal se realice hacia un sujeto rural aislado, atrasado o "indígena", ella no anticipa demandas sino que más bien responde a ellas y sale al paso a una dinámica acción colectiva e individual andina tras objetivos de modernización en materia de comunicaciones, conectividad, educación o acceso a servicios. Integración activa que arrastra directa e indirectamente una diversidad de cambios sociales, ideológicos y culturales que se precipitan durante el periodo y se prolongan después ${ }^{11}$.

El segundo momento corresponde al periodo autoritario (1973-1990) respecto del que pueden señalarse varios hechos. De inicio, para las regiones interiores de Arica, Iquique y Antofagasta no tiene vigencia la acción pública directa y de coordinación que estaba entregada al Instituto de Desarrollo Indígena (IDI), sucesor desde 1972 de DASIN según la Ley 17.927. De hecho, esta ley y el IDI cayeron en la inactividad, terminando por ser derogadas. Algunas de sus funciones fueron trasladadas a INDAP. No obstante, las "becas indígenas" que contemplaba esa ley mantuvieron vigencia y un cierto número de estudiantes aymaras y atacameños se beneficiaron de ayuda escolar. Luego, en una política no indígena y en algunos aspectos directamente antiindígena, una visión geopolítica de integración de regiones marginales y de reforzamiento de fronteras política y diplomáticamente sensibles preside y orienta la acción pública de esos años. La contingencia del centenario de la Guerra del Pacífico en la relación con Perú y Bolivia, y las serias tensiones políticas con Argentina en el llamado "Diferendo por el Beagle" explican en parte el enfoque mencionado. Lo anterior se complementa con una consistente voluntad política de integración territorial de regiones geográficas marginales, como el espacio andino del norte chileno. Integración que desde los poblados y comunidades andinas fue notoriamente bien recibida por sus residentes indígenas.
Presencia policial y militar autoritaria en el espacio andino, apoyada en una retórica de restauración del orden público, un manifiesto nacionalismo, la anulación de derechos civiles y políticos, control y regulación social, e intervención de las organizaciones de base caracterizan esa mayor vigencia de la acción estatal. Algunos dirigentes indígenas de izquierda se escondieron o emigraron de sus comunidades, otros debieron tolerar vigilancia y amenazas y se sabe de algunos muertos "desaparecidos". Son característicos del periodo una mayor presencia de agentes públicos, el funcionamiento continuo de establecimientos escolares, mayor diligencia en sostener y ampliar la conectividad terrestre, desarrollo de redes de radiocomunicación, campañas sociales y sanitarias a cargo de las fuerzas armadas, activación de celebraciones y ritualidad política nacionalista. Tres cursos de acción son importantes de hacer notar. Primero, el plan de escuelas de concentración fronteriza, dirigido al reforzamiento de la infraestructura y los servicios escolares en zonas extremas del país (extremos y márgenes geográficos, en prácticamente todos los casos asociados a fronteras políticas). Además de aumentar la cobertura escolar y mejorar los servicios, este proyecto se planteó como un instrumento de retención de población y, con ello, de reforzamiento de la soberanía en áreas de frontera. Los resultados fueron contradictorios por cuanto no atenuó la emigración desde las regiones andinas; antes al contrario, parece haberla facilitado por cuanto entregó instrumentos lingüísticos y educacionales para un mejor desenvolvimiento en otros sectores y actividades regionales. Segundo, la municipalización del espacio andino. A principios de la década de 1980 se crean municipios en todas las zonas interiores; previamente constituían anexos distantes de municipios cuyas cabeceras se encontraban en la costa o el desierto intermedio. Recursos, servicios entregados por los municipios y coordinación para la llegada local de otras agencias públicas podían así acercarse a los pobladores andinos. Debido a la condición designada de los alcaldes y de los presidentes de Juntas de Vecinos, además del manejo de lealtades de los funcionarios municipales, esta importante reforma fue también un eficiente dispositivo de control político y social de la población indígena.

Como tercer aspecto, resalta la impronta nacionalista de la acción del gobierno autoritario en las regiones andinas, entendida como formación 
discursiva rectora del sentido de la acción pública. Actúan en esa dirección el reforzamiento de un sentido de "chilenidad" mediante la actividad escolar, los rituales públicos celebratorios de la nacionalidad chilena y la inculcación nacionalista asociada a la presencia y actuar de personal de la policía y las fuerzas armadas. La puesta en funciones de los municipios otorgó el cuadro institucional perfecto para estas labores de inculcación, acción ritual y sentido nacional de la acción estatal. Pero también lo hace la insistencia en la demarcación de los que son "chilenos" respecto de los "peruanos" o "bolivianos", indígenas y más atrasados e, incluso, menos civilizados que los de "este lado". Y, si bien los pobladores andinos podían considerarse "indios" en el altiplano de Arica, Iquique o las comunidades de la cordillera de Antofagasta, la acción de las instituciones del Estado y sus fuerzas armadas permitiría un giro hacia un mayor progreso, civilización e integración de estos connacionales olvidados o poco atendidos por anteriores gobiernos. Es decir, podían dejar de ser "indios" o ser menos "indios" porque, como hemos dado a entender, esta categoría social se presenta en la historia regional indisolublemente asociada a carencia o ausencia relativa de civilización y progreso. Envolvía entonces la promesa de una emancipación de la condición de "indio", de la que, debemos consignar con claridad, la gran mayoría de ellos suscribía de manera acrítica. Pero también fueron manifiestas, especialmente en la zona aymara altiplánica, las dudas acerca de la nacionalidad de estos indígenas ${ }^{12}$ y su efectiva lealtad a Chile. De allí que el estado o condición de indígenas de estos "pobladores", como les llamaba la prensa regional, resultara problemático y ambiguo: por su carencia de progreso y civilización y por su proximidad física (frontera) y cultural (lengua, instituciones comunitarias, religiosidad) con los países vecinos representados como diferentes y hostiles a Chile. Soberanía e integración serán las claves políticas de la acción estatal autoritaria del periodo.

Del Acuerdo de Nueva Imperial en 1989, entre los partidos reunidos en la Concertación de Partidos por la Democracia, con Patricio Aylwin de candidato a la presidencia, y diversas organizaciones indígenas, participaron algunos dirigentes aymaras y atacameños. Con ello se da inicio a lo que será un cambio sustantivo de política para los indígenas aymaras, atacameños, quechuas, coyas y diaguitas del norte de Chile.

\section{Estado y reconocimiento étnico en el norte de Chile (1990 ---)}

La política indígena que inaugura la Concertación de Partidos por la Democracia durante el gobierno de Aylwin tiene continuidades notorias en relación con el pasado en materias como la creación de una institucionalidad que ejerce roles de mediación, coordinación y también ejecución de medidas de política, o en cuanto a participación de representantes y líderes indígenas. Pero también innova decisivamente o se propone profundizar mucho más en asuntos que estaban apenas esbozados en el pasado. Se trata claramente de una política de reconocimiento y que, por tanto, presupone derechos especiales para grupos particulares. No obstante, sus alcances son hasta ahora limitados; por ejemplo, respecto del rango del reconocimiento político buscado, en que no se ha logrado que quede consagrado en la Constitución del país. Esos grupos son ahora etnias, pueblos indígenas o pueblos originarios y ya no "indígenas" pobres, rurales, atrasados, en márgenes geográficos y marginalizados. Constituyen grupos discretos definidos por su especificidad sociocultural e histórica, perspectiva que reemplaza como visión dominante a la de categorías de población en posiciones relativas bajas, de rezago en cuanto a desarrollo social.

Mientras que para el caso mapuche o el rapanui esa condición de grupo particular (según criterios históricos, culturales, lingüísticos y políticos) está vívidamente presente en su conciencia colectiva, debido precisamente a las condiciones en que se planteó para ellos las relaciones de dominación modernas y neocoloniales que estructuraron sus nexos con regiones y país, ello fue bastante más difuso con los grupos indígenas del norte del país. Primero, porque esa vívida conciencia no existía, o era considerablemente ambigua y, en cualquier caso, referida no a grupos socioculturales discretos, sino que, como hemos insistido, a categorías de población transitivas respecto de ideologías de progreso y civilización. Luego, porque la experiencia histórica y social indígena de la que hablamos tenía, y con cambios en desarrollo todavía tiene, una fundamental referencia a la nacionalidad como principio de pertenencia y no a la etnia. En esas condiciones, puede sostenerse que se requirió en el norte del país una doble etnificación, en ambos casos desde arriba. Primero, de intelectuales y dirigentes indígenas, principalmente urbanos o con niveles 
socioeducacionales mayores, que desarrollaron una concepción de etnia y pueblo originario y que son llamados a ser partícipes de la elaboración de una nueva (más bien revisada) política indígena en los albores del retorno a la democracia. Todo esto bajo los términos de la Comisión Especial de Pueblos Indígenas (CEPI) creada al inicio del gobierno de Aylwin para estos fines. Durante su ejercicio, con la promulgación de la Ley $\mathrm{N}^{\circ} 19.253$ de octubre de 1993 y su puesta en funcionamiento, tiene lugar por esos representantes la construcción o confirmación de categorías, el desarrollo de definiciones étnicas y el establecimiento de fronteras de la etnicidad: llamarse "indígena" u "originario" o "nativo" o "indio" (como quisieron algunos) como categoría general más envolvente; definir los límites de lo "aymara" en Chile (su condición regional o más bien andina y por tanto trinacional, las semejanzas y diferencias con lo atacameño o con otras categorías urbanas "mestizas"); o los alcances de lo "atacameño" (respecto de lo quechua y de lo "coya", a quienes se adosaba tradicionalmente la condición de "indio"). Y, luego, como segundo momento, llevarlo a la gente, hacer todo esto extensivo a una población rural y urbana indígena o de origen indígena, no partícipe o al menos poco informada y frecuentemente desinteresada de la acción pública en curso y de lo que ello suponía como definiciones sociales. Pero también, luego de realizado todo eso, podrían resultar otras disputas por definiciones colectivas, desde bases sociales más heterogéneas de lo previsto. La autopercepción quechua en los valles de Tarapacá y Arica es decidor al respecto, buscando deslindarse de lo aymara, altoandino y "boliviano".

Desde un inicio tuvo lugar una nutrida interlocución de líderes, intelectuales y algunos dirigentes aymaras y atacameños con los funcionarios de gobierno encargados de la formulación de una nueva ley. Esta temprana presencia se manifiesta en adendas o acápites especiales de la Ley $\mathrm{N}^{\circ} 19.253$ referidos a ellos y en definiciones concernientes. Por ejemplo, respecto de los regímenes de propiedad. Por su parte, las etnias quechua y colla son mencionadas en la Ley Indígena de 1993 y en los documentos de la época, aludidas con la vaga expresión "y demás comunidades indígenas del norte de Chile". No participaron representantes suyos, salvo alguna asistencia colla, de la génesis de la ley, sus reuniones, deliberaciones, asambleas, audiencias públicas y presencia en el Congreso mientras se debatía la ley. De allí que un mejor conocimiento de su población, distribución, problemas y demandas recién se logró gracias al trabajo de la Comisión Especial de los Pueblos Indígenas (CEPI) y la Corporación Nacional de Desarrollo Indígena (CONADI) creada con la Ley $\mathrm{N}^{\circ} 19.253$, que sucedió a la anterior. En consecuencia, con retardo respecto de aymaras y atacameños, también en este caso la emergencia étnica se realizó con la inducción de funcionarios de CONADI y parlamentarios ${ }^{13}$; encontrando, eso sí, un terreno suficientemente abonado por la existencia de organizaciones, un Centro Cultural Colla, funcionaros municipales interesados y dirigentes con alguna información de los nuevos aires de reconocimiento étnico en curso.

La tardía activación del reconocimiento quechua $^{14}$ arranca de la acción desarrollada por el gobierno local de la comuna de Ollagüe que gestiona ante la Corporación Nacional de Desarrollo Indígena (CONADI), la definición quechua de organizaciones de la comuna constituidas en un primer momento como comunidad indígena atacameña, a lo que le siguen asociaciones y comunidades de la comuna de Calama. Los fundamentos del cambio fueron lingüísticos (algunas personas mayores sabían la lengua quechua y ello se recordaba como más extendido en la generación precedente) e históricos (las familias quechuas rastreaban su origen en personas emigradas a la zona desde la región Lípez en el departamento de Potosí, Bolivia). Estos arreglos de encasillamiento étnico no fueron conflictivos ni arrastraron divisiones durables, como lo muestra el hecho que las nuevas organizaciones quechuas no dudaron en integrar entidades de coordinación más amplias, por etnia o zona, donde prevalecen las atacameñas ${ }^{15}$.

Como los quechuas, collas y diaguitas activan tardíamente representantes, acción y voz en pro del reconocimiento étnico. Como bien lo ha señalado Molina (2013) para el caso colla, hay antecedentes previos de desplazamientos por la acción de la minería estatal en la zona de Potrerillos y El Salvador, y conflictos con propietarios de tierras en la parte alta del valle de Copiapó. En el diaguita debe considerarse el recuerdo de mejores oportunidades agrarias y de desarrollo durante la segunda mitad de la década de 1960 y luego con el gobierno de Allende, y más recientemente la amenaza de grandes proyectos mineros sobre las aguas o riesgos de contaminación y daños ambientales. Con todo y que su conformación como grupos políticamente 
activos regionalmente no surge de la nada, no constituye condición suficiente los reclamos y demandas surgidas desde comunidades locales, redes familiares y dirigentes por la acción de la minería en la zona cordillerana de la Región de Atacama (valle del Huasco) y la Región de Coquimbo (valles de Elqui). Para todas las etnias que emergen en un segundo momento, esa organización y su oficialización como pueblos originarios se hizo posible con el concurso de agentes públicos (CONADI en particular) y de parlamentarios de la Concertación de Partidos por la Democracia (coalición en el poder por esos años) en la regiones de Atacama y Coquimbo, respectivamente ${ }^{16}$.

La acción pública en las áreas étnicas del norte de Chile puede entenderse mejor contemplando la diversidad y envergadura de la actividad de las agencias públicas, o al menos su adecuación, en vistas del trabajo con pueblos originarios y sus organizaciones. Por una parte, la Corporación Nacional de Desarrollo Indígena (CONADI) cuenta con una Subdirección en Iquique y oficinas en Arica y Calama, despliega acciones propias en materia de desarrollo indígena, educación (intercultural y un muy demandado fondo de becas de estudio), cultura, tierras y aguas, y de coordinación de la labor de las oficinas gubernamentales hacia los pueblos indígenas. La variedad de funciones que se le asignó y lo inédito del volumen de recursos financieros que se le entrega encontró y encuentra demandas siempre en ascenso, por lo que generalmente prima una actitud de crítica e insatisfacción. Como sea, se está muy lejos de la tímida y modesta consigna de DASIN en la década de 1960 de apenas interesarse por los "indígenas" del norte del país.

En cuanto a su mandato de coordinación de la acción pública se han dado momentos y altibajos. A inicios de la década de 2000 solía entre los funcionarios públicos de la Región de Tarapacá hablarse de "con nadie", remedando a CONADI. En la Región de Antofagasta, sin embargo, se ha venido dando una relación mejor y más efectiva coordinación, en parte por la condición de minoría objetiva de atacameños y quechuas y su concentración en la provincia de El Loa. Así también, dependiendo de las señales y compromisos entregados por los intendentes y gobierno regional, la acción pública hacia los indígenas es más activa y coordinada.

Bajo los criterios de cobertura, integralidad y acción afirmativa está el mandato de que toda repartición pública debe realizar acciones en pro de la población indígena y ojalá con sus organizaciones presentes en la región. Así, cuando corresponde por las funciones que cumple, cada organismo contempla presupuestos y realiza acciones, proyectos, o programas (cuando su actividad hacia ellos tiene un horizonte más allá de la programación anual) ${ }^{17}$ con estos sectores de población. En algunos casos ello ha significado la incorporación de funcionarios y asesores o "facilitadores" indígenas. Por otra parte, las comunas andinas, controladas regularmente por alcaldes y concejales indígenas, aportan numerosos Consejeros Regionales que participan de aprobaciones presupuestarias, distribuyen importantes fondos regionales e impulsan proyectos, normalmente en cogestión con los propios municipios u organismos sectoriales. Ellos son un factor de presión importante para asegurar recursos hacia esas comunas y su población.

Pero como es posible suponer, detrás de los nombramientos en las Secretarías Regionales Ministeriales, los movimientos en las direcciones de servicios, la selección de intendentes y gobernadores y las elecciones de alcaldes y concejales se encuentran partidos políticos y coaliciones de gobierno y de oposición. Influyendo todo ello, a su vez, los diputados y senadores regionales con agendas políticas propias que deben poner en sintonía con aliados en los partidos, en la administración pública, los gobiernos locales y bases electorales. Entre otras, los indígenas urbanos y los de comunas rurales. Ellos han jugado papeles decisivos en la gestión del reconocimiento oficial diaguita (Ley No 20117 de 2006) y en la activación de la organización, en la interlocución política, la elaboración de demandas y acciones de defensa y promoción quechua y colla, como ya señalamos.

La reforma político-administrativa de 1979 realizada durante el gobierno de Pinochet contempló la creación de varios municipios en áreas andinas o con alta presencia indígena (General Lagos, Putre y Camarones en actual región de Arica y Parinacota; Camiña, Colchane, Huara y Pica en la de Tarapacá; y Ollagüe y San Pedro de Atacama en la de Antofagasta). Los municipios y los gobiernos locales que se democratizan a partir de 1992 han cumplido una labor decisiva en acercar la acción del Estado a zonas que previamente eran apenas anexos de municipios distantes (como San Pedro de Atacama respecto de Calama o Camiña respecto de Pisagua). Y ello, en cuanto a las funciones que son propias a los municipios, como de sus posibilidades 
de convocatoria y coordinación de la acción pública sectorial. A diferencia del caso mapuche, con una construcción histórica de las comunas de larga data y una estructuración social y política muy distinta, en el norte del país varios de los nuevos municipios son enteramente indígenas y, en otros, la población indígena es mayoritaria o muy cercana de serlo. Por tanto, regularmente los gobiernos locales han sido indígenas, con alcaldes de centroizquierda y derecha. Bajo su responsabilidad y la de los concejeros han recaído aspectos fundamentales de la relación indígena y de sus Juntas de Vecinos con las agencias públicas (gestación de acciones, negociación, convenios, coordinación), además de aquellas funciones que les son propias (por ejemplo, educación, asistencia primaria en salud o pequeñas inversiones en desarrollo local).

Las Áreas de Desarrollo Indígena (ADI), de las que hay cuatro en el norte indígena chileno, corresponde a un tipo de delimitación territorial con alta presencia indígena y suficiente homogeneidad como para justificar la focalización de la acción del Estado sobre ella ${ }^{18}$. El ADI Alto Andino en Arica y Parinacota y el ADI Jiwasa Oraje en Tarapacá, ambos aymaras; Atacama La Grande (atacameña) y Alto El Loa (atacameña y quechua), ambas en Antofagasta, son las creadas hasta ahora. A la organización de ellas concurren las comunidades indígenas constituidas en la zona, los organismos públicos, representantes de los municipios y el intendente regional o su representante. Hubo un periodo en el caso de Atacama La Grande en que también se invitó a empresas mineras con actividad en el espacio del Área de Desarrollo o su vecindad, pero la iniciativa no prosperó debido a que los dirigentes atacameños habrían centrado su interacción en reclamos y demandas por recursos y derechos territoriales y no, como esperaban las empresas, en la convergencia de esfuerzos públicos, privados e indígenas por desarrollo local. Con diferencias importantes de una a otra y según el impulso que las autoridades regionales quieran darle, las ADI han servido como un espacio para buscar acuerdos con autoridades y organismos públicos, lograr mayor coordinación, demandar exigibilidad de compromisos, más horizontalidad y posibilidad de evaluar la acción pública hacia las comunidades indígenas, pero se ha erigido también en una instancia para las reclamaciones indígenas hacia autoridades y organismos del Estado. A su vez, estos últimos y las autoridades regionales encuentran en las ADI un canal de llegada a la dirigencia indígena y de focalización de proyectos y transferencia de recursos.

Según lo indicado, las ADI han posiblemente ayudado a aminorar, o a hacer menos dramática, la saturación, sobreposición, a veces incoherencia, poca capacidad de aprendizaje y resiliencia de los organismos públicos en su acción con indígenas del norte del país. En efecto, las agencias estatales tienen culturas institucionales y modalidades de actuación e intervención propias (por ejemplo, Ministerio de Educación respecto del de Agricultura). Las programaciones y presupuestos anuales son una camisa de fuerza que con frecuencia los llevan a ejecuciones apresuradas. La exigencia de resultados mensurables y en plazos determinados es otro factor de presión, a lo que se agrega la ausencia de seguimiento de continuidad de resultados y efectos en el tiempo de las acciones emprendidas. La rotación de directivos, profesionales y técnicos es común. La actuación de cada organismo autónomamente con su propio proyecto o en el marco de programas particulares se suma a las características indicadas. Las consecuencias son de varios signos, algunas de ellas definitivamente problemáticas. Una es la pertinencia cultural, un eslogan recurrente. Nadie sabe muy bien en qué consiste eso y los intentos se mueven entre un ingenuo y por momentos grotesco tradicionalismo, hasta desistir de cualquier intento por esta vía. Otra es el traslape de la interlocución agrupada más allá de todo sentido común. Una pequeña localidad indígena atacameña, por ejemplo, debe desdoblarse en múltiples grupos de trabajo, comités, organizaciones formalizadas o no, con el resultado de una importante superposición de integrantes individuales y familias agobiados por tener que ser partícipes de tanto grupo, organización y comité y con poco tiempo para hacer efectivos los compromisos asumidos. Directamente conectado a lo anterior se encuentra la desproporcionada oferta de "proyectos", o a los que son vinculados, los indígenas individual y colectivamente considerados, sin que ellos tengan tiempo, compromiso o capacidades para abordar tantos asuntos que les son presentados, y respecto de los cuales las oficinas públicas buscan implicarlos. Pero como a los dirigentes suele medírseles por los proyectos "ganados" para su organización, comunidad o pueblo, entonces la aceptación con frecuencia irreflexiva de acciones de y con organismos públicos fuerza más allá de toda lógica las capacidades de respuesta indígenas (Gundermann, 2009). Efectos de lo anterior son 
previsibles: cumplimientos parciales, objetivos no logrados, pasividad de los receptores, o condicionamiento hacia los organismos responsables (minimizar contrapartes, salario caído, mayor autonomía en el uso de recursos, negación de auditorías, ausencia de informes de cumplimiento, etc. $)^{19}$. Con cada gobierno se vive un ciclo de este tipo. Cada gobierno suele impulsar las mismas o muy similares acciones que previamente demostraron ser inviables por errores de diseño, de interpretación de la realidad social indígena, por ausencia de capacidades técnicas o limitaciones en el actuar colectivo. Al respecto, los problemas de seguimiento de resultados son crónicamente repetitivos y la ausencia de aprendizajes vinculantes es lamentable.

$\mathrm{El}$ proyecto de reconocimiento indígena y acción afirmativa surgida con el Acuerdo de Nueva Imperial e impulsado con la Ley $\mathrm{N}^{\circ} 19.253$ hace crisis en la segunda mitad de la década de 1990. El no cumplimiento de acápites centrales del Acuerdo, la ruptura de la confianza y credibilidad a que llevó la aprobación del proyecto hidroeléctrico Ralco (1997) en conflicto con comunidades pehuenches y el escalamiento de demandas étnicas lleva a una sucesión de respuestas estatales: los Diálogos Comunales (1999); el reconocimiento constitucional indígena, frustrado durante varios intentos en el Parlamento; el Programa Orígenes (2001-2005), la Comisión de Verdad Histórica y Nuevo Trato (2001-2003); Re-conocer: pacto social por la multiculturalidad (primer gobierno de Bachelet); Comisionado Presidencial para Asuntos Indígenas (2008); la aprobación del Convenio 169 de la OIT (con vigencia desde septiembre de 2009); el Plan Araucanía (desarrollismo) en el gobierno de Piñera; y el Ministerio de Asuntos Indígenas, un Consejo de Pueblos Indígenas y una agenda de Desarrollo de los Pueblos Originarios (segundo Gobierno de Bachelet) con cumplimientos todavía inciertos ${ }^{20}$.

Lo que se acaba de reseñar debe entenderse, más ampliamente, en relación con demandas indígenas que se expanden y que adquieren nuevas dimensiones no previstas en la Ley Indígena o difícilmente abordables por esta. Para ello se han venido diseñando y poniendo en práctica fórmulas de política pública como las indicadas en el parágrafo precedente, con innovaciones de estilo o de metodología más que con transformaciones políticas sustantivas, a razón de una o dos por mandato presidencial, según los avatares y crisis en la relación con los pueblos indígenas. Esos programas o medidas de política responden a la situación de conflictividad mapuche y mucho menos a lo que ocurre con otros pueblos originarios; por ejemplo, la crítica que hacia la CONADI endilgan los pueblos indígenas del norte chileno, o las movilizaciones por la contaminación minera o la explotación de acuíferos en tierras reclamadas. Las etnias del norte se han adecuado a ese escalamiento de demandas desarrollando formulaciones etnopolíticas correspondientes, según las realidades que les son propias. Los congresos o reuniones amplias equivalentes que cada pueblo indígena ha realizado en la última década y media son el momento y el lugar para su manifestación. Destacan dos: territorios y autonomía. Esto es, la demanda por certidumbres jurídicas para la propiedad, el control y uso indígena de extensiones de tierras, aguas superficiales y subterráneas y recursos del subsuelo, considerados de ocupación histórica tradicional y respecto de los cuales se busca obtener la confirmación de derechos. También autonomía, en el sentido de poder ejercer un control, administración y gestión de esos territorios según instituciones y órganos de representación política propios en favor de los integrantes del pueblo originario vinculados a ese territorio. En zonas de frontera con tres países, con derechos preferentes al subsuelo por parte de compañías privadas que prácticamente tapizan todo el suelo nortino de pertenencias, una minería que representa más de la mitad de las exportaciones del país, con crecientes problemas de agotamiento de acuíferos para satisfacer la demanda urbana de aguas, puede entenderse la dificultad posiblemente irremontable para que estas demandas sean abordadas seria e integralmente. Hasta ahora, los recursos del Fondo de Tierras y Aguas de CONADI, un convenio con el Ministerio de Bienes Nacionales y con la Dirección de Aguas han permitido adquirir y regularizar algunas aguas (permanece pendiente el capítulo de las aguas subterráneas), traspasar tierras a comunidades indígenas (especialmente en el caso atacameño y el colla), pero avances efectivos en materia de autonomía y autogestión territorial no se han realizado.

\section{Conclusiones}

Vista en perspectiva, la relación histórica moderna de los pueblos originarios del norte del país con el Estado chileno reúne varias singularidades. Una de las más llamativas es la tardía visibilidad política o pública del "indígena” en el norte de Chile, 
tanto si se considera una percepción generalizada de esta categoría de personas en las regiones septentrionales, como cursos de acción estatal dirigidos a ellos. Esta es una materia que recién en la década de 1960 empieza tímidamente a asomar, se activa algo más durante el gobierno de Allende y, contra lo esperable o lo que se supone, no se elimina del todo durante el gobierno autoritario. Paradojas de la vida, uno de los más conspicuos ideólogos del indianismo aymara chileno de finales de la década de 1980 e inicios de la de 1990 hizo sus estudios con una beca indígena durante el gobierno de Pinochet.

La hipótesis que compartimos y hemos ayudado a formular para explicar esta diferencia considera varios aspectos. El hoy llamado Norte Grande incluye territorios anexados luego de una guerra que dejó a Chile como ganador. La heterogénea población que permaneció en y arribó a esas regiones fue categorizada según un código de tipificaciones estrictamente nacional: peruanos, bolivianos, chilenos, argentinos, otras nacionalidades, etc. Los documentos oficiales, de censos entre otros, se remiten exclusivamente a categorías de nacionalidad. Luego, debido a la percepción de autoridades y chilenos en general como un pueblo, una sociedad, una nación y un Estado superior a Perú y Bolivia, los perdedores, resultó congruente adjetivar a su población como atrasada o "bárbara". Y también como "indios" o "indígenas" a los integrantes de algunas de sus capas sociales. En estas se presentarían en mayor grado los males sociales indicados. Como se puede notar, la categoría que prima es la nacionalidad, correspondiendo lo que se adosa a ella sus adjetivaciones, las cualificaciones que desde una cierta visión imponen los vencedores; entre otras representaciones, la del peruano o boliviano "indio" 21 . La centralidad política de las pertenencias y adjetivaciones nacionales se intensificó notoriamente con la prolongada indefinición de soberanía, durante medio siglo, que vivieron Arica, Tacna y Tarata, ocupadas por Chile. El peso de la nacionalidad como objetivo e instrumento político se hace entonces muy presente regionalmente. Para esos lugares y situación puede en propiedad emplearse la noción de "chilenización", que más tarde ha servido, de un modo que creemos insuficiente y erróneo, para calificar la relación entre el Estado chileno y los pueblos originarios del norte del país hasta el presente. Es la integración de los otros nacionales, a veces adjetivados de "indios", lo que designa el vocablo "chilenización" y no la asimilación del aymara, el quechua, el likanantay o el colla.

En ausencia de cualquier política que abordara la especificidad cultural aborigen de los indígenas en estas regiones, la administración estatal y otras medidas de política pública los trató como cualquier otro habitante (por ejemplo, respecto de la propiedad). La excepción es la extendida percepción que asimilaba extranjeridad (peruana o boliviana) con condición indígena y, como consecuencia, la persistente sospecha acerca de sus lealtades nacionales; en especial por su concentración en zonas andinas que requerían de vigilancia y control fronterizo. Esa misma posición andina de sus principales grupos de población los dejó en márgenes administrativos respecto de las cabeceras políticas ubicadas en los puertos regionales (Arica, Iquique, Antofagasta) o ciudades mineras (Copiapó). Y aunque la economía minera -y actividades conexas- prevaleciente durante el siglo XX y actual los involucró en sus ciclos expansivos y crisis, su posición subalterna en ella ha sido una constante. El patrón de integración atacameño o colla asalariado en la minería o en servicios relacionados, frecuentemente trabajando en empresas tercerizadas, es el mejor ejemplo.

La culminación del ciclo salitrero a fines de la tercera década del siglo XX supuso importantes reacomodos de las poblaciones andinas, así como medidas paliativas y alternativas de desarrollo impulsadas por organismos del Estado. Entre las primeras, el inicio de las emigraciones a los centros urbanos y puertos del norte del país tanto por factores de expulsión (la articulación agropecuaria a la economía regional declina paulatinamente en intensidad) como de atracción (inicios de la industria pesquera, el Puerto Libre de Arica, su ulterior industrialización, pero también la expansión de la minería cuprífera en sitios como Chuquicamata y El Salvador-Potrerillos). Para las zonas andinas, la consolidación de una infraestructura de escuelas y retenes policiales fronterizos es de esta época postsalitrera. También algunas obras de infraestructura y organización asociada (cooperativas, centros de reforma agraria, obras de riego y drenaje, reforestación, apertura de áreas de cultivo) para el fomento agrícola de valles bajos y oasis busca mejorar el autoabastecimiento regional de alimentos y la retención de población rural. La década de 1960 e inicios de la siguiente es particularmente activa en estas materias, en línea con las profundas transformaciones agrarias que en ese entonces sacudían el país. Se advierte por esos esos 
años alguna visibilidad pública y acciones estatales hacia las poblaciones andinas que, explícitamente, se las identifica como indígenas. Durante el periodo autoritario la inversión en fomento agropecuario disminuye y las unidades económicas colectivas creadas en el periodo previo se disuelven o se les abandona a su suerte. Donde es el caso, la tierra se privatiza a sus poseedores, indígenas andinos y no indígenas. En la cordillera andina se intensifica la conectividad terrestre, aumenta la presencia policial, la militar, la administrativa con la creación de comunas y se impulsan planes educacionales especiales, en respuesta a las tensiones políticas que se vivieron con Perú, Bolivia y Argentina. Por medio de la acción escolar y de los nuevos gobiernos municipales se ejerció una sostenida activación nacionalista. Presidió este enfoque una visión geopolítica de soberanía y control político de regiones fronterizas.

Con el retorno a la democracia en 1990 se abre un nuevo escenario político-social para los pueblos originarios del norte del país. En lo principal, uno de reconocimiento de la condición de pueblos originarios ("etnia" recupera el texto de la Ley $\mathrm{N}^{\circ}$ 19253) con nombre propio (aymara, atacameño, quechua, colla y diaguita), y algunas acciones concomitantes (salud y educación intercultural). Pero, también, uno de desarrollo con algo de innovación y pertinencia (por ejemplo, las Áreas de Desarrollo Indígena) y mucho de acciones de fomento local que por lo general no son nuevas, aunque con presupuestos mayores si se los compara con el pasado. Un balance de este segundo componente en las regiones andinas de montaña muestra un aumento de infraestructura, servicios y subsidios sociales y productivos, pero en cuanto a sus resultados poco de expansión productiva o retención de población, y en cuanto a la acción estatal misma, todavía menos de coherencia, pertinencia y eficacia. Relativo a lo primero, apreciamos un reconocimiento nominal con pocos derechos políticos que suscita el escalamiento de demandas territoriales, de autonomía y autodeterminación, en correspondencia con modos de contención desde el gobierno interior y otras agencias públicas, nacionales y regionales. En la dialéctica de un escalamiento de la demanda de los pueblos originarios, sujetos a una paralela contención política, legal y administrativa desde el Estado, verificamos los límites del reconocimiento y los derechos colectivos.

\section{Referencias Citadas}

\section{Alvarado, Luis}

1970 La vida rural en el altiplano chileno, ICIRA, Santiago.

Bujes, Jacylin

2008 "Los Collas de Atacama: Identidad y etnogénesis", Tesis de licenciatura y título de Antropología, Universidad Academia de Humanismo Cristiano, Santiago.

Colompil, Daniel

1972 "Situación de la población indígena en Chile. Algunas líneas de acción de 18 meses de gobierno. Experiencias y posibilidades futuras". Ponencia presentada en el VII Congreso Indigenista Interamericano, Brasilia, 8 de agosto de 1972, Ms.

Comisión de Verdad Histórica y Nuevo Trato

2008 Informe de la Comisión de Cerdad Histórica y Nuevo Trato con los Pueblos Indígenas. Biblioteca del BicentenarioPehuén, Santiago,

Díaz, Alberto

2006 "Aymaras, peruanos y chilenos en los andes ariqueños: Resistencia y conflicto frente a la chilenización del norte de Chile" Revista de la Asociación de Antropólogos Iberoamericanos en Red, $\mathrm{N}^{\mathrm{o}}$ 1, vol. 2, pp. 275-289, Madrid, España.

Díaz, Alberto (compilador)

2006 Los andes. Entre el Tributo y la Nación. Las comunidades aymaras en el norte de Chile durante el Siglo XIX. Colección Estudios Regionales. Universidad Bolivariana, Santiago.
Díaz, Alberto, Rodrigo Ruz y Carlos Mondaca

2004 "La administración chilena entre los aymaras: resistencia y conflicto en los Andes de Arica (1901-1926)". Anthropológica $\mathrm{N}^{\mathrm{o}}$ 22: 215-235.

Díaz, Alberto y Rodrigo Ruz

2009 Estado, escuela chilena y población andina en la ex Subdelegación de Putre: acciones y reacciones durante el periodo postguerra del Pacífico (1883-1929)" Polis, vol. 8, $\mathrm{N}^{\mathrm{o}} 24: 311-340$.

Díaz, Alberto, Luis Galdamez y Rodrigo Ruz

2010 Nación e identidad en los Andes indígenas de Arica y Estado chileno (1883-1929). Ediciones Universidad de Tarapacá, Arica.

Díaz, Alberto, Rodrigo Ruz y Luis Galdamez

2013 "En los intersticios de la chilenidad: Antonio Mollo y las identidades en conflicto en los Andes. Putre, 19001926" Chungara, Revista de Antropología Chilena, vol. 45, $\mathrm{N}^{\circ} 3: 473-492$.

Díaz, Alberto y Marcela Tapia

2013 "Los aymaras del Norte de Chile entre los Siglos XIX y XX: un recuento histórico". Atenea $\mathrm{N}^{\circ} 507$ : 181-196.

Díaz, Alberto, Germán Morong y Carlos Mondaca

2015 "Entre el archivo y la etnografía. Reflexiones historiográficas desde la periferia del Norte de Chile". Diálogo Andino No 46:107-121. 
Gobierno de Chile 1972 Mensaje del Presidente Allende ante el Congreso Pleno, 21 de mayo de 1972. Santiago: Talleres Gráficos del Servicio de Prisiones.

González, Héctor

1996a Características de la migración campo ciudad entre los aymaras del norte de Chile. Documento de Trabajo, Corporación Norte Grande, Arica.

González, Héctor

1996b Los migrantes aymaras en la ciudad: acceso a educación, vivienda y salud. Documento de Trabajo, Corporación Norte Grande, Arica.

González, Héctor

2002 "Los aymaras de Tarapacá y el periodo republicano temprano (1821-1879)". Documento de Trabajo, Comisión de Verdad Histórica y Nuevo Trato. Santiago.

González, Héctor; Hans Gundermann y Jorge Hidalgo

2014 "Comunidad indígena y construcción histórica del espacio entre los aymara del norte de Chile", en Chungara, Revista de Antropología Chilena, vol. 46, № 2: 233-246.

González, Sergio

1997 “Maestras chilenizadoras y peruanistas", en Boletín de Educación, UCN, Antofagasta.

González, Sergio

2002a Chilenizando a Tunupa. La escuela pública en el Tarapacá Andino (1880-1990), DIBAM, UNAP, CIHDBA, Santiago.

González, Sergio

2002b "El Estado chileno y el mundo andino: los efectos de la guerra del salitre", Documento de Trabajo, Comisión de Verdad Histórica y Nuevo Trato. Santiago.

González, Sergio, Carlos Maldonado y Sandra McGee

1994 "Las ligas patrióticas: un caso de nacionalismo, xenofobia y lucha social en Chile" en CanadianReview of Studies in Nationalism, XXI (12).

Gundermann, Hans

2001 "Comunidad, sociedad andina y procesos socio-históricos en el Norte de Chile", Tesis doctoral, Centro de Estudios Sociológicos. El Colegio de México.

Gundermann, Hans

2002 "Sociedad aymara y procesos de modernización durante la segunda mitad del siglo XX”,Documento de Trabajo, Comisión de Verdad Histórica y Nuevo Trato. Santiago.

Gundermann, Hans

2013 "Procesos étnicos y cultura en los pueblos indígenas de Chile", en Alpha, Revista de artes, letras y filosofía, $\mathrm{N}^{\circ} 36$ : 93-108.

Gundermann, Hans

2013 "Aymara: las relaciones interculturales", en Pueblos originarios y sociedad nacional en Chile. La interculturalidad en las prácticas sociales, Programa de las Naciones Unidas para el Desarrollo (PNUD), Editor Durston, John, Santiago de Chile, pp. 51-71.

Gundermann, Hans

2013 "Los atacameños y sus relaciones interétnicas", en Pueblos originarios y sociedad nacional en Chile. La interculturalidad en las prácticas sociales, Programa de las Naciones Unidas para el Desarrollo (PNUD), Editor Durston, John, Santiago de Chile, pp. 81-97.

Gundermann, Hans

2013 "Los quechuas y sus relaciones interétnicas", en Pueblos originarios y sociedad nacional en Chile. La interculturalidad en las prácticas sociales, Programa de las Naciones Unidas para el Desarrollo (PNUD), Editor Durston, John, Santiago de Chile, pp. 73-79.

Gundermann, Hans, Rolf Foerster y Jorge Iván Vergara 2003 Mapuches y aymaras. El debate en torno al reconocimiento y los derechos ciudadanos, PREDES, Ril Editores, Santiago.

Gundermann, Hans, Jorge Iván Vergara y Alberto Díaz

2011 "Historia moderna de una lengua originaria: el jaqiaru en Chile", en RLA Revista de lingüística teórica y aplicada, vol. 49(1): 69-108.

Gundermann, Hans; González, Héctor y Durston, John

2014 "Relaciones sociales y etnicidad en el espacio aymara chileno" en Chungara. Revista de Antropología Chilena, vol. 43(3): 397-421

Gundermann, Hans y Vergara, Jorge Iván

2009 "Comunidad, organización y complejidad social andinas en el norte de Chile" en Revista Estudios Atacameños. Arqueología y Antropología Surandinas, No 38, pp. 107-126.

Kessel, Johanes van

1992 [1981] Holocausto al Progreso. Los aymaras de Tarapacá, Hisbol, La Paz (edición ampliada de la publicación de CEDLA en Holanda, 1981).

Molina, Raúl

2013 "Los collas: identidad y relaciones interculturales en Atacama", en Pueblos originarios y sociedad nacional en Chile. La interculturalidad en las prácticas sociales; Programa de las Naciones Unidas para el Desarrollo (PNUD), Editor Durston, John, Santiago de Chile, pp. 99-113.

Molina, Raúl

2013 "Diaguitas: emergencia étnica y dialéctica de las relaciones y conflictos interculturales en el Huasco Alto", en Pueblos originarios y sociedad nacional en Chile. La interculturalidad en las prácticas sociales; Programa de las Naciones Unidas para el Desarrollo (PNUD), Editor Durston, John, Santiago de Chile, pp. 115-125.

Tudela, Patricio

1992 Transformación religiosa y desintegración de la comunidad aymara tradicional en el norte de Chile. Tesis Doctoral, HologVerlag, Bonn, Alemania.

Tudela, Patricio

2002 "El estado y la sociedad chilena ante los Aymaras de Tarapacá (1ra. Región de Chile): factores y consecuencias de su integración entre 1930-1973", Documento de Trabajo, Comisión de Verdad Histórica y Nuevo Trato. Santiago.

Vergara, Jorge Iván, Gundermann, Hans y Foerster, Rolf

2013 Estado, conflicto étnico y cultura. Estudios sobre pueblos indígenas de Chile, Editorial Ocho Libros Editores, Santiago de Chile. 
$1 \quad$ Agradecemos los comentarios de dos lectores anónimos de este trabajo, especialmente por la sugerencia de artículos y trabajos históricos previamente no considerados que entregan información y emprenden análisis de materias abordadas aquí. Incorporamos en el texto y en la bibliografía las recomendaciones que consideramos pertinentes y de mayor interés.

2 De particular interés para la comprensión de la capacidad de agencia indígena en la relación con el Estado es la propuesta de una historia desde la "periferia nortina", el "borde investigativo" y la "historia local", integrando el archivo y la etnografía que un grupo de historiadores reunido en el Taller Tincu, al alero de la Universidad de Tarapacá. Agradecemos la mención de que nuestras investigaciones han constituido una fuente de inspiración para su trabajo historiográfico y de integración disciplinaria. Por el carácter más general y sintético de este artículo no hemos citado en extenso las numerosa obra hasta ahora producida por este grupo. Para mayores detalles consúltese Díaz, Morong y Mondaca, 2015.

3 La cronología que proponemos atiende al foco o asunto central del estudio: las relaciones entre Estado chileno y pueblos originarios, con énfasis en los modos y los medios con los que el Estado concibió y trató a los indígenas en el norte de Chile. Por cierto, otras cronologías son posibles respecto del tema (por ejemplo,, Díaz y Tapia, 2013). Al mismo tiempo, se intenta establecer las características y transformaciones de esos grupos, junto con las reacciones y respuestas que las poblaciones genéricamente rotuladas de indígenas mantuvieron hacia los organismos públicos. Mencionamos, a la vez, algunos cambios que esa misma interacción fue generando. Reconocemos así una cierta capacidad de agencia indígena, sin llegar a concebir esa autonomía más allá de la condición de dominación y subalternidad que se impuso a esas relaciones desde fines del siglo XIX y principios del XX.

4 Ocasionales referencias a la condición aymara o atacameña las encontramos en diplomáticos, visitantes ilustrados o etnólogos. Pero ello no debe llamar a engaño, ya que las autoridades y funcionarios suscriben siempre la nacionalidad como la categoría social y políticamente significativa.

5 Ambigua y problemática en tiempos modernos. A veces empleada externamente como apelación rebajatoria y estigmatizante; recogida otras tantas como afirmación de una pertenencia colectiva y rebelión ante el estigma. Los mitos y relatos que retrotraen esa indigenidad a los "tiempos del Inca", con frecuencia "la muerte del Inca", consignan un origen y proveniencia, pero hasta muy recientemente no una diferencia desde la que se haya establecido una alteridad social y políticamente significativa. Constatar estas ambigüedades ayuda a entender en los grupos indígenas septentrionales aquí tratados la preferencia por las adscripciones locales y las nacionales, en ausencia de una historia social de diferencias, conflictos y luchas en tanto grupos particulares, que sirven de fundamento a una fuerte pertenencia e identificación colectiva mapuche y rapanui.

6 Las "estancias" o unidades de pastoreo altoandino fueron en su momento inscritas como propiedad privada por uno o más poseedores. Debido al carácter extensivo y especializado del pastoreo de camélidos sudamericanos domésticos (llamas y alpacas) y ovinos, esas unidades no son susceptibles de divisiones menores sin afectar su viabilidad productiva, por lo que en la mayoría de los casos se mantuvieron como propiedades indivisas de familias extensas que siguieron un régimen patrilineal de residencia. Por tanto, no se trata de un tipo de comunidad tradicional, sino que el resultado sociológico de la puesta en funciones de un régimen de propiedad moderno adaptado a un sistema socioproductivo ganadero andino particular (Alvarado, 1970; Gundermann y González, 1997).

7 Hoja de coca desde Bolivia, por ejemplo, para consumo entre los trabajadores de la minería. O la exportación de fibra de camélidos desde Arica, el comercio en la cordillera con fibra de vicuña, el traslado de licores y telas de la textil Bellavista Tomé a Bolivia, lo mismo que productos electrónicos cuando se desarrolla esta industria en la ciudad de Arica durante la década de 1960.

8 Notoriamente, el texto de la Ley $\mathrm{N}^{\circ} 14.511$ se titula: "Establece los Juzgados de Letras de Indios que señala y fija normas sobre división de comunidades, liquidación de créditos y radicación de indígenas", publicada el 3 de enero de 1961 .

9 Esto último quedaba reservado en lo sustancial para los estudios etnológicos y el conocimiento histórico especializado.

10 Mensaje del Presidente Allende ante el Congreso Pleno, 21 de mayo de 1972.

11 En materia de educación, consúltese a González S.,2002a y Gundermann, 2014. En el religioso a Tudela, 1992.

12 Se comentaba, por ejemplo, que ellos podían fácilmente asimilarse con los indígenas bolivianos, que la lengua que mantenían los emparentaba con ellos, lo mismo que sus costumbres, celebraciones y rituales colectivos, actividades y hábitos familiares. Que muchos tenían también documentos bolivianos, doble nacionalidad y parientes y vinculaciones allá, etcétera.

13 "Referente a los primeros acercamientos con la Ley Indígena, relata que dos años después de que Patricio Aylwin promulgara la Ley Indígena (1993), se acercan el Subdirector Nacional y el Director de Desarrollo de Conadi, Antonio Mamani y Cornelio Chipana, respectivamente, hacia la gente del Centro Cultural Colla. En donde instigan a los habitantes de Potrerillos para incluirse dentro de la Ley. Otro instigador fue el Senador Ricardo Núñez y su esposa. Desde 1995, entonces, Conadi-Norte comienza a dirigir los primeros recursos para realizar una investigación y propia búsqueda de los originarios colla. En esas mismas fechas nacen las tres primeras comunidades que al mismo tiempo delimitarían los espacios de presencia colla en la cordillera. Sin embargo, según los testimonios, muchos se quedaron en silencio y no supieron reconocerse por vergüenza y baja autoestima referida a su identidad" (Bujes, 2008:89).

14 Recordemos que el concepto étnico "quechua" está de inicio presente en el texto de la ley, pero esos primeros años no hubo representación, presencia o vocería quechua en las elaboraciones que estamos reseñando.

15 Pero tal adecuación es válida para la Región de Antofagasta y no para la de Tarapacá (que por aquel entonces incluía 
Arica y Parinacota). Durante la década de 2000 más notoriamente algunas localidades de valles de la Región de Tarapacá se constituyeron como comunidades o asociaciones quechuas, en una zona principalmente aymara. Más allá de los antecedentes históricos, mitológicos, ideológiconacionalistas, geográficos y culturales esgrimidos, esto debe entenderse como una reacción derivada de la insatisfacción que se tenía en los valles precordilleranos con la acción de CONADI, y la percepción crítica acerca del control de esta institución por aymaras urbanos de familias provenientes de comunidades altiplánicas de la frontera con Bolivia, o decididamente de familias inmigrantes al país.

16 Un buen ejemplo es el diaguita. Inició gestiones en 1998 la gobernadora de la provincia de Huasco, luego ministra de educación, Yasna Provoste Campillay, con autorreconocimiento como diaguita. En agosto de 2002 se presentó al Parlamento la modificación de la Ley 19.253 por los diputados Jaime Mulet, Antonio Leal, Alberto Robles y el exdiputado Carlos Vilches. La Cámara de Diputados lo aprobó el 15 de julio de 2004 y el Senado el 19 de julio de 2006.

17 En este último caso CONADI, Ministerio de Educación, Instituto de Desarrollo Agropecuario, Ministerio de Bienes Nacionales, Corporación Nacional Forestal, entre otros. Están contempladas en la ley indígena en los términos siguientes: "espacios territoriales en que los organismos de la administración del Estado focalizan sus acciones en beneficio del desarrollo armónico de los indígenas y sus comunidades" art.25, Ley $\mathrm{N}^{\circ} 19253$.

19 Los fenómenos reseñados se hicieron muy visibles durante los años en que se realizó el Programa Orígenes (en los hechos,
2001 a 2010 aproximadamente). Se trata de una iniciativa de apoyo a la organización, el fomento de cultura e identidad, la capacitación para ganar competencias organizativas y los proyectos locales de desarrollo. Fue financiado por un importante crédito internacional (BID) y se debe entender como un tipo de respuesta política desde una perspectiva de desarrollo local al avance de las demandas indígenas que entierran el Acuerdo de Nueva Imperial ya a fines de la década de 1990. El Programa Orígenes se prolongó por varios años, con cierres de proyectos y transferencias a organizaciones indígenas pendientes hasta por una década. Primó una metodología participativa y de empoderamiento de dirigentes en la gestación, ejecución y cumplimientos de proyectos. El Programa se vio sobrepasado por problemas de gestión, siendo uno de ellos las considerables dificultades que enfrentó en la exigibilidad del uso de recursos financieros y los resultados de proyectos.

20 Decayeron bastante las expectativas respecto de lo que pudiera hacer la Comisión Asesora Presidencial de la Araucanía. Las demandas territoriales y por autonomía no son recogidas suficientemente en el informe del 23 de enero de 2017 que esta Comisión entregara a la presidenta Bachelet, según el parecer de algunos intelectuales mapuches con quienes se consultó este tema.

21 Por lo demás, ya no en el plano del conflicto y de las tensiones entre países, sino en el de la sociedad peruana regional del siglo XIX, el sistema de clases y estratificación regional situaba al indígena no como un estamento colonial, como una categoría discreta, sino más bien una transitiva. Ello no cambió con la anexión a Chile hasta muy avanzado el siglo XX, como hemos indicado. 
